\title{
A MÁRKÁK PÉNZÜGYI ÉRTÉKELÉSÉNEK MÓDSZEREI
}

A szerző́ tanulmányában rámutat a márkák pénzügyi szempontból történő értékelésének jelentôségére, és ismerteti a márkaértékelés pénzügyi módszereit. Minthogy az erôs márkák a vállalatok értékéhez nagyban hozzájárulnak, valamint általuk - a no name termékekhez képest - nagyobb profit realizálható, a márkák pénzügyi értékelésének a menedzseri döntésekben fontos szerepe van. A márkaértékelés pénzügyi módszerei közt megtalálhatók (teljesen) objektív alapokon nyugvó, racionális technikák és a fogyasztói értékítéletet magukban foglaló eljárások is; minden esetben azonban az értékelés céljának legmegfelelóbb módszert kell választani. A cikk ismerteti a márkák pénzügyi értékelésének jelentését és céljait, a pénzügyi és a fogyasztói értékelés kapcsolódási pontjait, a márkák erejét kifejezó közgazdasági modellt, a márkákat mint a vállalatok értékét meghatározó vagyontárgyakat, valamint részletesen szól a márkaértékelés pénzügyi módszereiról.

Kulcsszavak: márka, márkamenedzsment, pénzügy

A márka egy nevet, kifejezést, jelet, szimbólumot, designt, vagy ezek kombinációját jelenti, egységes definíciója azonban nem létezik. A márkák fejlesztésének célja, hogy a termékeket, szolgáltatásokat és/vagy a vállalatot azonosítsák és megkülönböztessék a versenytársaktól (Kotler, 1999). A pénzügyi értékelés szempontjából a márka olyan eszközként határozható meg, amelynek nincs fizikai formája, és amelynek pontos értéke nem állapítható meg anélkül, hogy az egy értékesítési és beszerzési üzleti tranzakció tárgyává ne válna (Seetharaman - Nadzir - Gunalan, 2001). A marketingszakemberek a márka erősségét annak fogyasztói szempontjából határozzák meg, a pénzügyesek viszont az alapján, hogy a márka gazdasági eszköz. Elméletben a két perspektíva összeegyeztethetó, mivel a márka nem tud a fogyasztók (nagyon) kedvezó értékelése nélkül magas árrést elérni, másrészt pedig az erôs márka lehetővé teheti a növekedést a fogyasztói preferencián keresztül. Gyakorlatban azonban nehéz lehet értékelni a legtöbb elterjedt marketing-mutatószám és a pénzügyi teljesítmény közti kapcsolatot (Mills, 2005).

A márkaértékelés egy márka neve és imázsa által létrejött dologi értékhez pénzügyi értéket határoz meg. A márkának mint megfoghatatlan eszköznek az értékelése folyamán bizonyos mértékú becslésre és szubjektivitásra van szükség. Az eredményesség mértékeként is szolgál a márkaérték, és a márkákkal kapcsolatos menedzseri döntésekben fontos szerepe van. A vállalatok számára továbbá az egyik leghatékonyabb eszköz lehet a márkaértékelés, hogy fejleszszék a pénzügy, a számvitel és a marketing területén dolgozó szakemberek együttmúködését a stratégiai márkamenedzsmentben. A hatékony márkaértékelés megköveteli a különbözố vállalati funkciók kooperációját, ugyanakkor szüksége is van a vállalat különböző osztályairól származó adatokra, információkra a stratégiai márkamenedzsmenttel kapcsolatos döntéshozatal során (Cravens - Guilding, 1999, 2000; Intangible Business, 2002).

A márkák pénzügyi értékelésére számos célból kerülhet sor. Fontos különbséget tenni a technikai és a kereskedelmi jellegú értékelések között. Technikai értékelést általában mérlegbeszámoló, adótervezés, pereskedés, elzálogosítás, licenceladás és franchising, fúzió és felvásárlás, valamint befektetői kapcsolatok céljából készítenek. Az elsődleges cél ekkor egy adott időpontra vonatkozó érték meghatározása. A kereskedelmi értékelés jellemzően a belsố menedzseri döntéseket támogatja, és dinamikusan méri a 
márka teljesítményét. Alkalmazzák piacstratégiával, portfóliómenedzsmenttel, büdzséallokációval és márka-scorecarddal kapcsolatban is (Mills, 2005; Haigh, 2003; Haigh - Knowles, 2004; Farquhar - Han - Ijiri, 1992; Bahadir - Bharadwaj - Srivastava, 2006; Doyle, 2002).

A világ legnagyobb márkáinak pénzügyi értékelését és rangsorolását minden évben elkészítő Interbrand munkája legfóbb céljának azt tekinti, hogy demonstrálják az üzleti világ számára: a márka nagyon fontos üzleti, és sok esetben a vállalat egyedülálló, legértékesebb eszköze (Best Global Brands, 2006, 2007). Fernández (2002) a márkaértékelés folyamatára hívja fel a figyelmet, minthogy az segít felismerni és meghatározni a márka értékére hatást gyakorló tényezőket, továbbá pedig növeli a vállalat által a márkáról rendelkezésre álló információkat.

\section{A márkák pénzügyi és fogyasztói értékelése}

A márkák pénzügyi értékelése az 1980-as évek közepén jelent meg és kezdett elterjedni. A márkafelvásárlási hullám volt az a 80-as évek végén, amely felszínre hozta az erốs márkákkal rendelkezô vállalatok rejtett értékét, és előtérbe helyezte a márkák pénzügyi értékelését (Seetharaman - Nadzir - Gunalan, 2001). Ezzel szemben a marketingorientált mutatókat, amelyek a fogyasztók szempontjából mérik a márkaértéket, már lényegesen régebb óta és szélesebb körben alkalmazzák. A napjainkban alkalmazott pénzügyi módszerek azonban jobban kvantifikálják a márkák által képviselt értéket. Ezek az új technikák, amelyek pénzügyi szempontból mérik a márkák teljesítményét, hagyományos üzleti értékelési modellek és gazdasági eszközök keverékéből származnak. Lehetôvé teszik továbbá, hogy a vállalatok pontosabban határozzák meg a márkák erôsségét, következésképpen pedig, hogy jobb menedzseri döntéseket alapozzanak meg (Brymer, 2004).

A márkaértékelés egyik szélsőséges pontját az objektív alapokon nyugvó, racionális pénzügyi módszerek, a másikat pedig a szubjektív jellegú, érzelmek vezérelte személyes észlelésre épülő marketingtechnikák jelentik (1. ábra). Az elóbbire példa a - késóbbiekben ismertetésre kerülố - költségalapú megközelítés, az utóbbira pedig a GfK által számos termék- és szolgáltatás kategória esetében világszerte alkalmazott BPImutató, amely a márka pszichológiai erôsségét méri. Napjainkban mind többen törekszenek arra, hogy összekapcsolják a két különböző szempontból történő megközelítést és egy holisztikusabb nézőpontú, a márka valódi értékét mind jobban kifejező értékelést végezzenek; ennek egyik példája az Interbrand módszer, amelyet szintén bemutatok (Brymer, 2004).

\section{1. ábra}

\section{A márkaértékelő rendszerek} tartománya

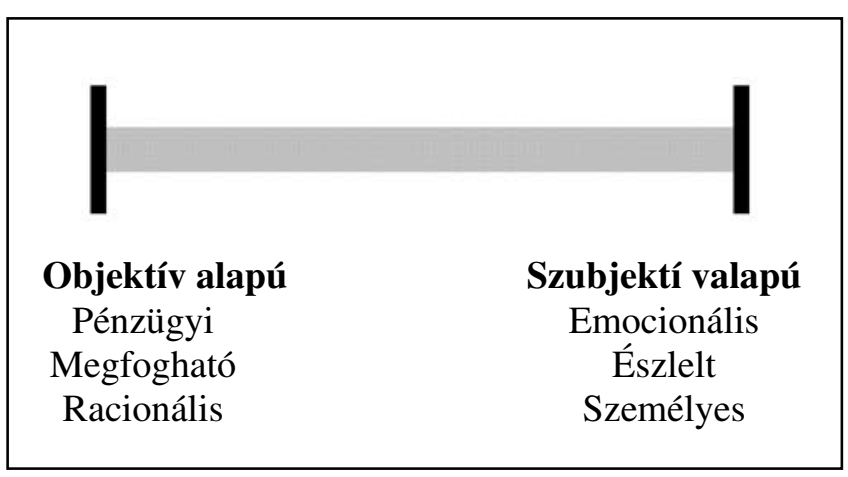

Forrás: Brymer, 2004

A marketing és a pénzügy márkaértékelésben való összekapcsolódásának fontosságát a márkaértéklánc is kifejezi. A marketing- és márkaberuházásokból indul ki, ehhez kötődik a fogyasztói márka értéke, amelyet olyan dimenziók határoznak meg, mint a fogyasztói tudatosság, asszociációk, attitúdök vagy húség. A következő láncszemet a márka piaci teljesítménye képezi, ez olyan tényezókből tevődik össze, mint például a piaci részesedés, az árprémium, az árrugalmasság vagy a költséghatékonyság. Végül, ez határozza meg a részvényesi értéket, a $\mathrm{P} / \mathrm{E}$ arányt és a részvényárat (Srivastava - Shervani - Fahey, 1998; Keller - Lehmann, 2003; Thomas - Parkhurst, 2006).

Haigh - Knowles (2004) modellje még nagyobb hangsúlyt helyez a márkák pénzügyi értékre gyakorolt hatására (2. ábra). A szerzópáros az érintettek négy csoportjából kiindulva vizsgálja a kifejlesztett márka értékének pénzügyi dimenzióit. A fogyasztók az általuk értékelt márkáért hajlandóak magasabb árat fizetni, újravásárlásokat végezni, ez pedig növeli a fogyasztói húséget. A keresleti oldalról így a fogyasztói márka értéke bevételnövekedést idézhet elő. A szállítókkal kedvezôbb üzleti feltételek érhetők el az erős márkák esetében, ez valójában alacsonyabb költségeket tesz lehetővé. A márkás termékeket piacra vivő vállalatok alkalmazottai motiváltabbak, és jobban kötődnek cégükhöz. Ez lehetôvé teheti mind a munkahatékonyság javulását, mind a munkaeróköltség csökkentését. A legfontosabb pedig, hogy a márka képes csökkenteni a tốkeköltséget az üzleti kilátások, befektetốk és finanszírozók általi észlelésének befolyásolásával (Haigh - Knowles, 2004). 


\section{A márka pénzügyi értékre gyakorolt hatása}

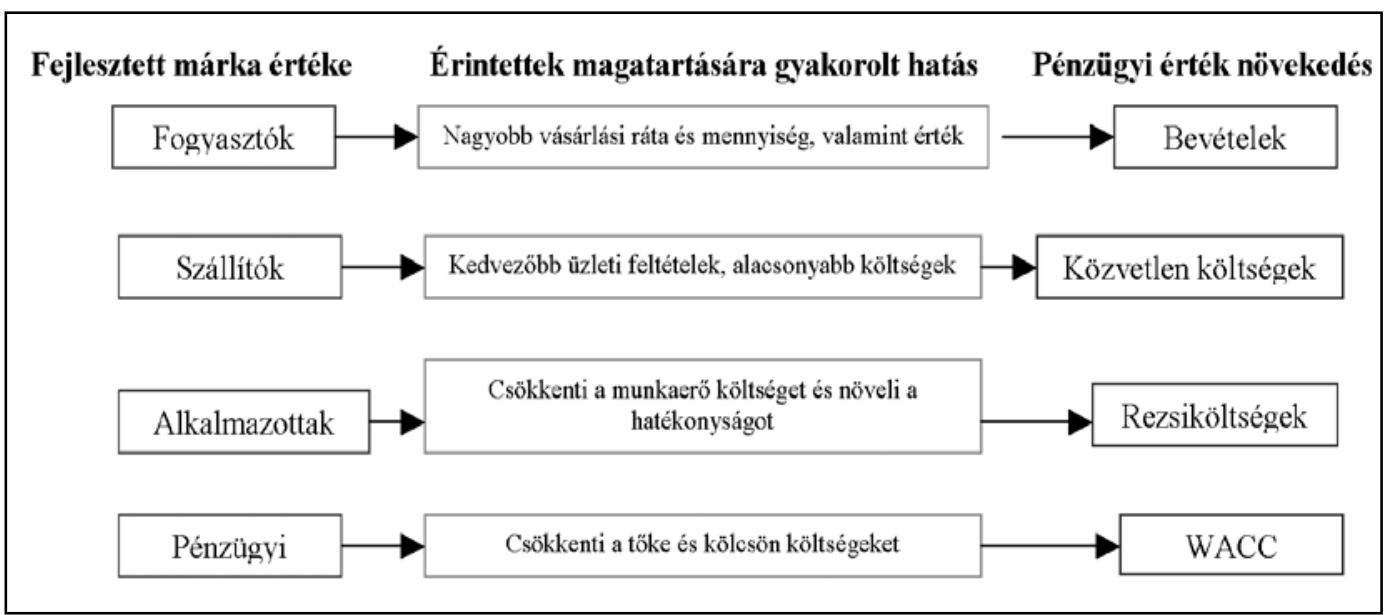

2. ábra (erre már a fentiekben is utaltam).

$\mathrm{Az}$ erôs márka tehát nettó nyereséget jelent mind a fogyasztók, mind a vállalat számára (4. ábra). Minthogy a keresleti és a költséggörbe ellentétes irányba mozdul el, a vállalat nagyobb profitot realizálhat, és a fogyasztói hasznosság többlete is emelkedhet.

A normál javak közgazdasági modellje

\section{A márkagazdaságtan alapjai}

Az alábbiakban a márkák jelentőségére a rájuk vonatkozó közgazdasági háttér rövid feltárásával mutatok rá mind a keresleti, mind a kínálati oldal szempontjából.

A normál, nem márkás termékek esetét a 3. ábra szemlélteti. Az e javak iránti kereslet mennyisége csökken, ha az ár növekszik. A fogyasztói többlet hasznossága nettó nyereséget jelent azon fogyasztók számára, akik az adott kínálati áron megvásárolják a terméket, azonban hajlandóak lettek volna többet is fizetni érte.

Az erôs márkával rendelkezô termékek esetében a keresleti görbe jobbrafelfelé tolódik. Ez egyrészt azt jelenti, hogy adott ár mellett a fogyasztók több márkás terméket fognak vásárolni vagy több szolgáltatást fognak igénybe venni. Másrészról, legtöbbször a keresleti görbe még rugalmatlanabbá válik. Ez azt jelenti, hogy a fogyasztók által vásárolt mennyiség stabil marad még akkor is, ha az ár emelkedik. Nem váltanak tehát át másik termék fogyasztására, mert az nem tudja azokat a megfoghatatlan elönyöket nyújtani, amelyeket a szóban forgó márka (esetében a fogyasztók értékelnek).

Az erôs márkák a kínálati görbe balra-lefelé történő tolódását idézik elő. Ez annak a következménye, hogy a márkával kapcsolatos költségek csökkennek

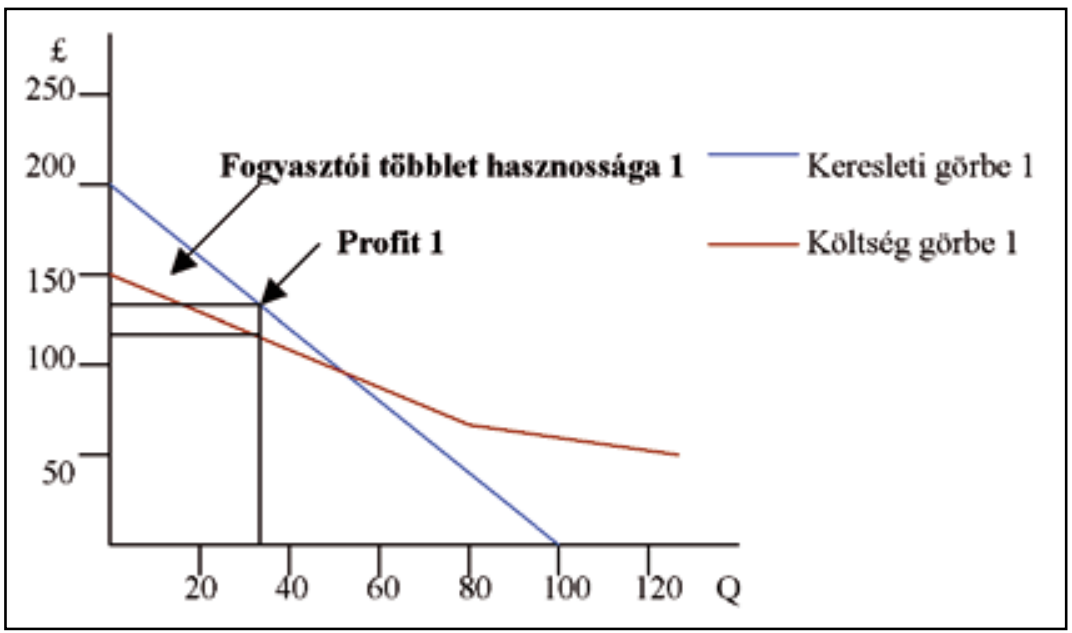

Forrás: Principles of BrandEconomics - Adding Brand Value, 2004

4. ábra

A márkák erejét kifejező közgazdasági modell

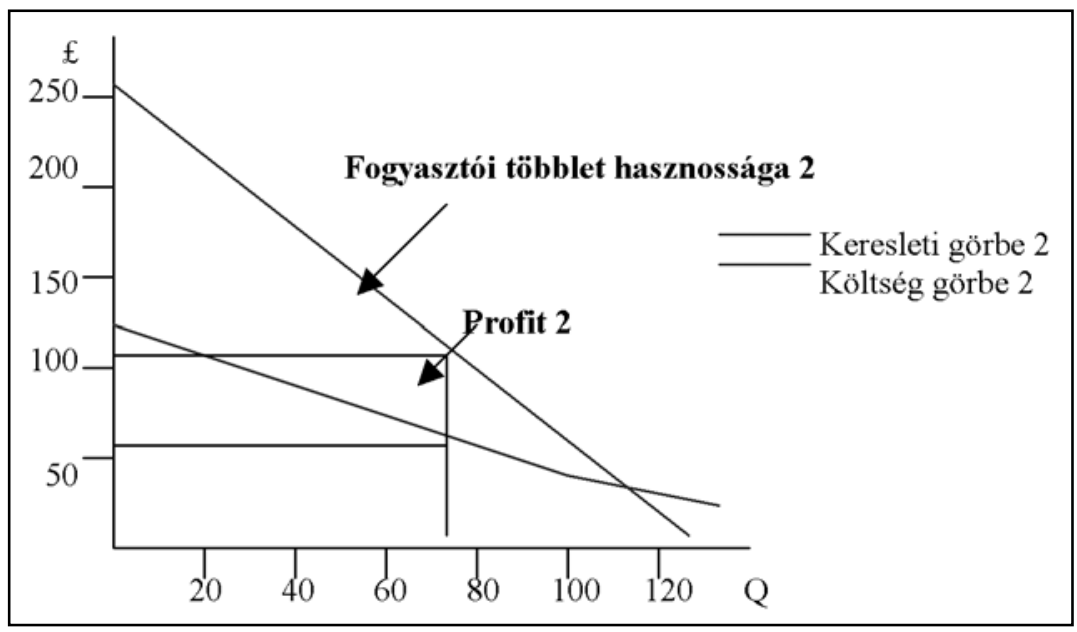

Forrás: Principles of BrandEconomics - Adding Brand Value, 2004 


\section{Márkaeszközök, a vállalatok legfontosabb értékmeghatározó eszmei vagyontárgyai}

Az 1980-as évekig a megfogható eszközöket, vagyis a gyártóberendezéseket, a földet, az épületeket vagy a pénzügyi eszközöket tekintették az üzleti érték fó forrásának. A piac tudatában volt az eszmei vagyontárgyaknak, de az egyedi értékük tisztázatlan maradt, nem kvantifikálták óket pontosan. Ez azonban nem azt jelenti, hogy a menedzserek nem ismerték fel a megfoghatatlan eszközök jelentőségét. A márkák, a szabadalmak, a technológia és az alkalmazottak mindig is a vállalati siker kulcsfontosságú elemei voltak, ritkán határozták meg viszont az explicit értéküket. Az eszmei vagyontárgyak mértéke akkor kapott egyre nagyobb figyelmet, amikor folyamatosan növekedett a rés a vállalatok könyv szerinti értéke és tôzsdei értékelése között, valamint a fúziók és felvásárlások során a tôzsdei értéken felül kifizetett felár erôsen növekedett a 80-as évek végén (Lindemann, 2004).

Az aggregált piaci - könyv - szerinti értékarány az S\&P 500 esetében a 80-as évek elejei 1,4-ról - folyamatos emelkedéssel - a 90-es évek közepére 3,5-re nőtt, ezt követôen gyorsabban, végül 7,3-del érte el csúcsát a dot.com buborék kipukkanásakor; 2003-ra visszaesett 4,7-re ez az értékarány (Haigh, 2003; Knowles, 2003; Haigh - Knowles, 2004). Ambler elemzései szerint a nagy multimárkás FMCG vállalatok esetében a piaci értéknek átlagosan 50\%-át adja a márkaérték (Jones, 2005). Az Interbrand különböző piacokra vonatkozó becslését a márkák, az egyéb megfogható és megfoghatatlan eszközök relatív jelentőségére vonatkozóan az 5. ábra szemlélteti. A Brand Finance számítása szerint is az egyes szektorok márkái közül a divat és a kozmetikai márkák hozzájárulása a legnagyobb a vállalatok értékéhez. A 2006-os kalkulációi alapján a Nike márka adja a legmagasabb, mintegy $84 \%$-os hányadot vállalata értékéhez. A Prada 77\%-os, az Avon és a Bulgari 68\%-os, a Chanel 66\%os, az Estée Lauder 61\%-o, a Quicksilver pedig 60\%-os márkaértéket képvisel a teljes vállalati értékben (BrandFinance250, 2007).

Napjainkban az üzleti érték többsége általában a megfoghatatlan eszközökből származik. Avery (1942) alapján Vaughan
(1972) a megfoghatatlan eszközöket kezdetben biztos (határozott) és bizonytalan (határozatlan) élettartamúakra osztotta. Az elóbbibe különbözố szerzôdések, egyezmények, jogok tartoznak, az utóbbiba a márka, továbbá például a technológiai know-how és a piaci elfogadás (Wilson, 1986). Az IAS az eszmei vagyontárgyak öt nagy csoportját különbözteti meg: a marketinggel összefüggóket, az ügyfelekre vonatkozókat, a szerződésalapúakat, a technológiaalapúakat és a múvészeti jellegúeket (Global Intangible Tracker, 2006). Haigh (2003) négy kategóriáját határozza meg a megfoghatatlan eszközöknek:

1. tudás (szabadalmak, szoftverek, speciális tudás),

2. üzleti folyamatok (üzleti/vállalati folyamatok megszervezésének egyedi módjai),

3. piaci pozíció (pl. kiskereskedelmi szerződések, disztribúciós jogok, licencek, termelési és importkvóták),

4. márka és kapcsolat.

Ágazatonként különbözik e négy csoportnak a relatív jelentôsége. A gyógyszeriparban a tudás, a kiskereskedelemben az üzleti folyamatok összehangoltsága, hatékonysága vagy rugalmassága, a légi közlekedésben pedig a piaci pozíció rendkívül fontos és a versenyképesség meghatározója.

A márka egy különleges, és számos vállalat esetében a legfontosabb eszmei vagyontárgy, nemcsak a fogyasztási javak terén, hanem a technológia és kutatás vezette szektorokban is, mivel a márkák ekkor kulcsfontosságú szerepet játszanak a vállalat technológiai kompetenciáinak piaci sikerré váltásában (Haigh, 2003). Mindez a márkák rendkívül nagy gazdasági hatásából követ-

5. ábra

A márkák és a többi eszköz relatív jelentôsége

\begin{tabular}{|l|c|c|c|c|}
\hline \multicolumn{1}{|c|}{ Piac } & Márka & $\begin{array}{c}\text { Egyéb meg- } \\
\text { foghatatlan } \\
\text { eszközök }\end{array}$ & $\begin{array}{c}\text { Megfogható } \\
\text { eszközök }\end{array}$ & Összesen \\
\hline Luxusjavak & 70 & 5 & 25 & 100 \\
\hline Étel és ital & 55 & 5 & 40 & 100 \\
\hline Pénzügyi szolgáltatások & 30 & 50 & 20 & 100 \\
\hline Gépkocsi & 30 & 20 & 50 & 100 \\
\hline Információs technológia & 20 & 50 & 30 & 100 \\
\hline Kiskereskedelem & 15 & 15 & 70 & 100 \\
\hline Gyógyszer & 10 & 50 & 40 & 100 \\
\hline Ipar & 5 & 25 & 70 & 100 \\
\hline Közszolgáltatások & 0 & 30 & 70 & 100 \\
\hline
\end{tabular}

Forrás: Shaw - Merrick, 2005: p. 257. 
kezik. Befolyásolják a fogyasztók, az alkalmazottak, a befektetốk és az állami hatóságok választásait, valamint egyre nagyobb szerepet játszanak a kereskedelmi siker és a részvényesi érték létrehozása szempontjából (Lindemann, 2004; Harter et al., 2004).

Napjainkban már számos számviteli standard, így az IAS is, megengedi és/vagy megköveteli, hogy a vásárolt márkák szerepeljenek a mérlegben. A saját fejlesztésúek viszont nem kerülhetnek be a mérlegbe. (A McDonald's mint márka így például nem szerepel a vállalati mérlegben, a Nestlé által megvásárolt Rowntree és a Danone által megszerzett Nabisco értéke viszont belekerül.) Nehéz megérteni azt, hogy miért kell a megvásárolt márkákat biztonságosabb és értékesebb vagyontárgyaknak tekinteni, mint a vállalat által kifejlesztetteket. Problémát okoz azonban még az, hogy nincsen szakmai konszenzus a márkaértékelés módszeréról. Egyes vállalatok márkaspecifikus értékelési technikákat (Interbrand, ABV) alkalmaznak, mások viszont kevésbé kifinomult eljárásokat, amelyek gyakran megkérdőjelezik a mérlegbe bekerült márkaértékeket. Az egységes pénzügyi márkaértékelési módszer hiánya, a technika szabad megválasztása kétségbe vonhatja a márkák mérlegbe történó beillesztésének egész folyamatát, illetve annak eredményét. (A különbözô módszerek ugyanis teljesen eltérô értékelésre vezethetnek.) A megvásárolt márkáknak mérlegben való megjelenése, mint az eszközökról történó jobb információnyújtás, mindenképpen előrelépést jelent a részvényesek számára. A saját fejlesztésú márkák mérlegból való kimaradásával azonban erôsen torzulhat egy adott vállalatról kialakuló kép. A McDonald's márka például nincs feltüntetve a vállalati mérlegben, a vállalat tốkepiaci értékének azonban mintegy 70\%át adja (Best Global Brands, 2006, 2007; Mills, 2005; Lindemann, 2004; Doyle, 2002).

\section{A márkaértékelés pénzügyi módszerei}

A márkák pénzügyi és fogyasztói értékelésének folyamatosan jelennek meg új modelljei és módszerei. Számuk napjainkban már meghaladja az ötszázat, ezek közül azonban csak mintegy 25-30 alkalmas a márkák pénzügyi értékének mérésére (Aak - Brokaw - Miljan, 2004). A márkák pénzügyi értékeléséhez teljesen más technikákra van szükség, mint a részvények és a fix eszközök értékének meghatározásához, az alapelvek azonban megegyeznek (Laboy, 2005). A márkaértékelés módszerének kiválasztását és alkalmazását megelôzôen két fontos kérdést kell megválaszolni:

1. Mit akarunk értékelni: a védjegyet, a márkát vagy a márkacéget?
2. Mi a célja az értékelésnek? Technikai vagy kereskedelmi (Haigh, 2003; Haigh - Knowles, 2004; Mills, 2005)?

A márkák pénzügyi értékelésének módszereit rendszerint négy kategóriába sorolják:

1. költségalapú megközelítések,

2. piaci alapú megközelítések,

3. jövedelemalapú megközelítések,

4. szabályszerú megközelítések (Cravens - Guilding, 1999).

Az alábbiakban részletesen ismertetem ezeket.

\section{A költségalapú megközelítések}

A költségek alapján történő márkaértékelés során vagy a márka létrehozásához vagy a márka helyettesítéséhez szükséges összköltség kalkulációja történik.

Az elsố megközelítés a márka értékét a márka létrehozásához, fejlesztéséhez és menedzseléséhez kapcsolódóan felmerült költségek összegeként határozza meg egy adott időpontra vonatkozólag ${ }^{1}$. A márkára vonatkozó múltbeli költségek elsôsorban a termékkoncepció kutatás-fejlesztésével, a piaci teszteléssel és a promócióval függenek össze (Cravens - Guilding, 1999; De Chernatony - McDonald, 2005).

A történelmi költségeken alapuló értékelés könynyen érthető, azonban számos gyengesége van. Alapvető problémája e módszernek, hogy a márkába történô minden befektetést számításba vesz; e megközelítés tehát azt feltételezi, hogy nincsenek olyan költségek a márkaépítés során, amelyek nem hatékonyak (De Chernatony - McDonald, 2005). Ebből az is következik, hogy a márkák értékét csökkenti, ha fejlesztésük, menedzselésük során valamilyen formában vagy területen hatékony költséggazdálkodást érnek $\boldsymbol{e l}$, mivel így alacsonyabb összköltség adódik. Ez viszont ellentmond a racionális alapon nyugvó pénzügyi márkaértékelésnek. Ezen értékelési módszer alapján összehasonlítva a márkákat emiatt tehát téves következtetésekre juthatunk.

Az érett márkák esetében az is kérdéses, hogy időben meddig célszerú visszanyúlni a költségek meghatározásához, minthogy azok többsége nehezen meghatározható (Cravens - Guilding, 1999).

További problémája a módszernek, hogy az idôsebb márkákat túlértékelheti, hiszen egy százéves márka esetében már valószínúleg több beruházás történhetett, mint egy húszévesnél (De Chernatony - McDonald, 2005). Ugyanakkor azonban félrevezetó következtetések vonhatók le abból adódóan is, hogy a gyenge márkák gyakran többletkiadásokat igényelnek (Aak - Brokaw - Miljan, 2004). 
Gyakran nehéz azonosítani azokat a költségeket, amelyek nem közvetlenül a márkának tulajdoníthatók, de mégis szerepet játszanak az életciklusa során (Cravens - Guilding, 1999). Különösen a marketingkiadásokon belül nem könnyú elkülöníteni a márkaépítéshez hozzájáruló költségeket (Shaw - Merrick, 2005). Vannak olyan ráfordítások is, mint például a technológiai szakértelem, amelyeket fontos lenne kalkulálni, azonban nehéz meghatározni az értéküket hasznuk megfoghatatlan természetének következtében (Cravens - Guilding, 1999).

Egy nagyon fontos felismerés az, hogy nincs, vagy alacsony a korreláció a márkába történó befektetés és az általa hozzáadott érték között (Global Intangible Tracker, 2006; Lindemann, 2004). Ez véleményem szerint nagyrészt azzal magyarázható, hogy egy márka sikere alapvetôen kvalitatív és megfoghatatlan tényezốktől függ - úgymint például az imázsa, a személyisége, az üzenete, az egyedisége (és ezek menedzsmentje), minthogy az valójában egy „összetett szimbólum" (Kotler, 1999: pp. 491.) -, és nem pedig a belé fektetett összeg nagyságától. Ennek alapján gyengesége a módszernek az is, hogy semmiféle kvalitatív tényezốt nem vesz számításba (De Chernatony - McDonald, 2005).

Ez a legkonzervatívabb értékelési módszer, kevés jövőre vonatkozó információt nyújt a márkamenedzselés folyamatához. A számviteli szakemberek, szemben a marketingesekkel, szívesen alkalmazzák ezt a módszert, mivel összhangban áll az eszközértékelés számviteli gyakorlatával (Cravens - Guilding, 1999). Valószínúleg ennek tudható be, hogy a bíróság általában e módszerek alapján kéri a márkák pénzügyi értékének meghatározását (Haigh - Knowles, 2004).

A helyettesítési költségek alapján történó megközelítés azt jelenti, hogy mennyibe kerülne a márka pótlása a jelenlegi gazdasági és üzleti helyzetben. Ez a módszer jobban tükrözi a márka valódi költségét egy adott időpontban, ez azonban nem függ össze annak nyílt piaci értékével (Mills, 2005; Farquhar - Han - Ijiri, 1992). Hátránya továbbá, hogy nagyon szubjektív értékelési módszer (Cravens - Guilding, 1999). Az újrabeszerzési érték meghatározása azért is nehéz feladat, mert az erős márka egyedi, tehát nem egy rutinkalkulációról van szó (Doyle, 2002).

A márkák pénzügyi értékelése során a költségalapú megközelítéseket ritkán alkalmazzák, mivel a márkára vonatkozó összköltség, vagy a márkába történó befektetések összege lényegesen alacsonyabb, mint a márka valódi értéke, és amelyen az tulajdonost cserélhet (Whitwell, 2007; Thomas - Parkhurst, 2006; Global Intangible Tracker, 2006).

\section{A piaci alapú megközelítések}

A piaci alapon történó márkaértékelés - szemben az elôzôvel - a vállalat keretein kívüli szempontból történik. E módszer annak az összegnek a becslését jelenti, amennyiért a márka eladható. Minthogy azonban a legtöbb márkának nincsen valódi piaca, nehéz megbecsülni a piaci értéket. A márka piaci értékét nagymértékben az általa várhatóan generált jövóbeni hozamok jelenre vetített értéke határozza meg. A márkák piaci értékének meghatározásakor a pénzügyi piac becsléséból indulnak ki; a vállalat teljes piaci értékébôl a megfogható eszközök értékét, azaz a vállalat mérlegében szerepló eszközök könyv szerinti értékét levonva adódik a megfoghatatlan eszközök, majd pedig a márka értéke (Cravens - Guilding, 1999; Seetharaman - Nadzir - Gunalan, 2001; Simon - Sullivan, 1993). Ezen a topdown megközelítésen alapul a Brand Economics által alkalmazott módszer is (Mills, 2005).

A módszer elônye a vállalaton kívüli megközelítési mód, azonban még reálisabb lehet az értékelés, ha létezik hasonló márka a piacon, amellyel össze lehet vetni az értékelendő márkát (Cravens - Guilding, 1999; Seetharaman - Nadzir - Gunalan, 2001). Ha a hasonló márkával rendelkező vállalatot például a könyv szerinti értékének a háromszorosáért értékesítették, akkor ezt a többszöröst lehet alkalmazni az értékelésre kerülő vállalat esetében is. A vállalat így kalkulált értékéból a fentiekben leírtak szerint becsülik a márka értékét. E módszer hátránya, hogy nehezen alkalmazható több márkát, valamint márkázatlan termékeket is piacra vivő vállalatok esetében (Doyle, 2002). A megfoghatatlan eszközök számos típusához hasonlóan, a márkák esetében is ritka az, hogy azt a cég más eszközeitốl elkülönítve értékesítik; emiatt pedig nehéz összehasonlításhoz megfelelő márkaeszköz-értékesítési árat találni (Global Intangible Tracker, 2006).

Az összehasonlíthatóság legfő́képpen azért nehéz a márkák esetében, mert azok fejlesztése során pontosan arra törekednek, hogy azok egyediek, megkülönböztethetóek legyenek, és ne pedig hasonlóak egy másikhoz (Lindemann, 2004). A módszer hátránya továbbá, hogy a márkák értékesítéséról kevés információ áll rendelkezésre, és még hogyha vannak is információk, azok csak korlátozottan alkalmazhatók más márkáknál (Shaw - Merrick, 2005), fóként az egyedi jelleg és a megfoghatatlanság miatt.

\section{Jövedelemalapú megközelitések}

A jövedelemalapú módszerek a márka által létrehozott várható jövốbeni jövedelmek jelenértékét határozzák meg. E megközelítések közül a legfontosabb a diszkontált cash flow, az árprémium és a royalty alapján történő értékelés. 
A diszkontált cash flow módszer a leggyakrabban alkalmazott márkaértékelési forma az egész világon, és az egyetlen, amelyet a vállalatok alkalmazhatnak a megvásárolt márkák értékelésére a mérlegben történô megjelenítésük céljából (Aak - Brokaw - Miljan, 2004). E modell a márka által a jövóben várhatóan generált cash flow jelenértékét becsli (6. ábra) (Thomas - Parkhurst, 2006; Cravens - Guilding, 1999; Laboy, 2005). Aak Brokaw - Miljan (2004), rámutat azonban a széles körben alkalmazott DCF-módszer hátrányaira is; minthogy a márkának az értéke és az életciklusa nagymértékben függ a külsố piaci körülményektốl, problémás lehet, hogy miként becsüljük meg a jövốbeli $\mathrm{K}+\mathrm{F}$ kiadások és a márka cash flowjának összegét, valamint életciklusát és az alkalmazandó diszkontrátát. Az is kérdéses, hogy mennyiben megfelelő a beruházás-elméletben használt módszert változatlanul átvenni a megfoghatatlan eszközök jövőbeli értékének mérésére. értékesített mennyiséggel vagy a piaci részesedéssel együtt (Shaw - Merrick, 2005).

A licencszerződés szerinti, a márka tulajdonosa számára fizetendő éves royalty alapján is becsülhetô a márkaérték, amelynek nagysága általában a licencvevő(k) értékesítésének egy meghatározott százaléka. Ez elsôsorban a nemzetközi piacokon versenyzô márkák esetében alkalmazható (Cravens - Guilding, 1999). A világ legnagyobb márkáinak értékelésével és rangsorolásával foglalkozó Brand Finance is a várható jövóbeli royalty-kat diszkontálja a márkaérték meghatározásához (BrandFinance250, 2007; Schultz - Schultz, 2005). Gyakran alkalmazott értékelési módszer, mert az adóhatóságok és a bíróságok a royalty rátára nagy figyelemmel vannak, fóként mivel sok licencszerződés érhetô el nyilvánosan (Haigh - Knowles, 2004).

DCF-alapú márkaértékelési modell

\begin{tabular}{|c|c|c|c|}
\hline Pénzügyi elemzés & Márkavezérelt elemzés & , & Márkakockázat \\
\hline $\begin{array}{l}\text { Szegmens szint } \\
\text { (üzleti egység, } \\
\text { márka, ország) } \\
\text { releváns hozamok }\end{array}$ & $\begin{array}{l}\text { Márkahatás } \\
\text {,Egyéb” megfog- Márlás kulcs } \\
\text { hatatlan eszközök \%-a }\end{array}$ & $\begin{array}{r}5^{-} \\
1 \\
1 \\
1 \\
1 \\
1 \\
1 \\
1 \\
1 \\
1 \\
1 \\
1 \\
\text { \%-a }\end{array}$ & $\begin{array}{l}\text { Kockázat mérséklés } \\
\text { Egy márka egyéni } \\
\text { kockázata, amely a } \\
\text { jövőbeli hozamok } \\
\text { fenntarthatóságát } \\
\text { befolyásolja }\end{array}$ \\
\hline
\end{tabular}

Forrás: Thomas - Parkhurst, 2006.

$\mathrm{Az}$ árprémium módszer szerint a márkás termék árát viszonyítják a márka nélküli termékéhez. E módszer hátránya, hogy túlértékeli a kis mennyiségben és nagyon magas áron értékesített márkákat, így például a luxusmárkákat, és alulértékeli a nagy volumenben és alacsony áron piacra kerülő márkákat (Cravens - Guilding, 1999). Egy másik megközelítés alapján a márkaértéket a két ár közötti különbség és a márkás termék értékesített mennyiségének szorzata adja. Az árprémium-technika problémája, hogy gyakran nehéz hasonló „no name” terméket találni, másrészt pedig, hogy azt feltételezi, minden márka esetében árprémium, stratégiát alkalmaznak (De Chernatony - McDonald, 2005). Az árprémium ugyanakkor nem mindig, vagy nem teljesen tükrözi a márka hatását, hanem csak az

\section{6. ábra}

\section{Szabályszerü megközelítések}

\section{Interbrand módszer}

Az Interbrand a márkaértékeléssel foglalkozó vezetó cégek egyike, az általa kifejlesztett módszer népszerú a márkáikat értékeló vállalatok körében. Az Interbrand a márkaértéket hasonlóképpen származtatja, mint ahogy $\mathrm{P} / \mathrm{E}$ arányból kalkulálható. A P/E arány a részvényérték és a részvényegységre jutó hozam, az Interbrand márkaszorzó pedig a márka értéke és a márka által generált profit hányadosa:

\section{márkaszorzó = márkaérték/márkaprofit}

Ebból a márkaérték:

\section{márkaérték = márkaprofit x márkaszorzó}

Kizárólag a márkának tulajdonítható profit meghatározásakor a márkás termékek által generált profitból kivonjuk a márkához nem kapcsolódó jövedelmeket. Ez utóbbiak becslése leggyakrabban úgy történik, hogy kiszámítjuk a márka termelésében lekötött tőkével mekkora várható hozam érhetô el egy hasonló, márkázatlan termék piacra vitele során. A márka által generált profit meghatározásakor feltételezzük, hogy a jövôbeni profit a jelenlegihez hasonló nagyságú lesz, mivel a márkastratégiában nem történik változás. A jövőbeli éves profit nagyságát az előző három a részvény piaci értéke a 
év profitjának átlagaként kalkuláljuk úgy, hogy a folyó évre háromszoros, az előzó évre kétszeres, az azt megelőző évre pedig egyszeres súlyt alkalmazunk - ezzel csökkenthetố a rendkívüli éves teljesítmények hatása - és minden egyes év profitját az infláció mértékével kiegyenlítjük.

A márkaszorzó nagyságának meghatározásához a márkaerôsség kiszámítására van szükség, minthogy ez határozza meg a márka jövôbeli hozamának megbízhatóságát. Az Interbrand a márka erôsségét hét tényező alapján határozza meg - az egyes tulajdonságokra adható maximális pontszámok zárójelben szerepelnek, összegük 100:

1. vezetô szerep (25): a piaci részesedés és a profitabilitás között szoros kapcsolat van, így a vezető márkák értékesebbek, mint a kis piaci részesedésúek,

2. stabilitás (15): azok a márkák, amelyek hosszú időn keresztül megtartják imázsukat és a fogyasztók húségét magas pontszámmal díjazzák,

3. piac (10): a stabil, bôvülô, magas belépési korlátokkal rendelkezó piacon jelen lévő márkák nagyobb pontszámot érnek el, mint a nehezen elôre jelezhető, kockázatos piacon versenyzők,

4. nemzetközi szerep (25): a nemzetközi elfogadottsággal és vonzerővel rendelkezó márkák értékesebbek, mint a hazai vagy a regionális piacon múködốk,

5. fejlődési irányvonal (10): az egyenletes fejlődésú márkák magasabb pontszámot kapnak,

6. támogatás (10): azok a márkák erôsebbnek tekinthetók, amelyekbe rendszeres befektetés történik, és támogatást kapnak,

7. védelem (5): a bejegyzett védjeggyel rendelkező márkák magasabb pontszámot érnek el.

Tehát minél magasabb összpontszámot ér el a márka, annál erősebbnek tekinthetố, és egyben annál kisebb kockázat kapcsolódik hozzá.

Az Interbrand szerint $S$ alakú görbével jellemezhetó a márkaerősség (pontszáma) és a márkaszorzó közötti kapcsolat (7. ábra). Az új márkák lassan növekednek életciklusuk elején, majd exponenciálisan, amint külpiacokon is elfogadottá válnak, ezt követốen pedig lelassulnak a globális márkává válás folyamatában (De Chernatony - McDonald, 2005; Doyle, 2002).

A márkaerôsség és a szorzó közötti kapcsolat 
8. ábra ben történő megjele-

Az ABV modell

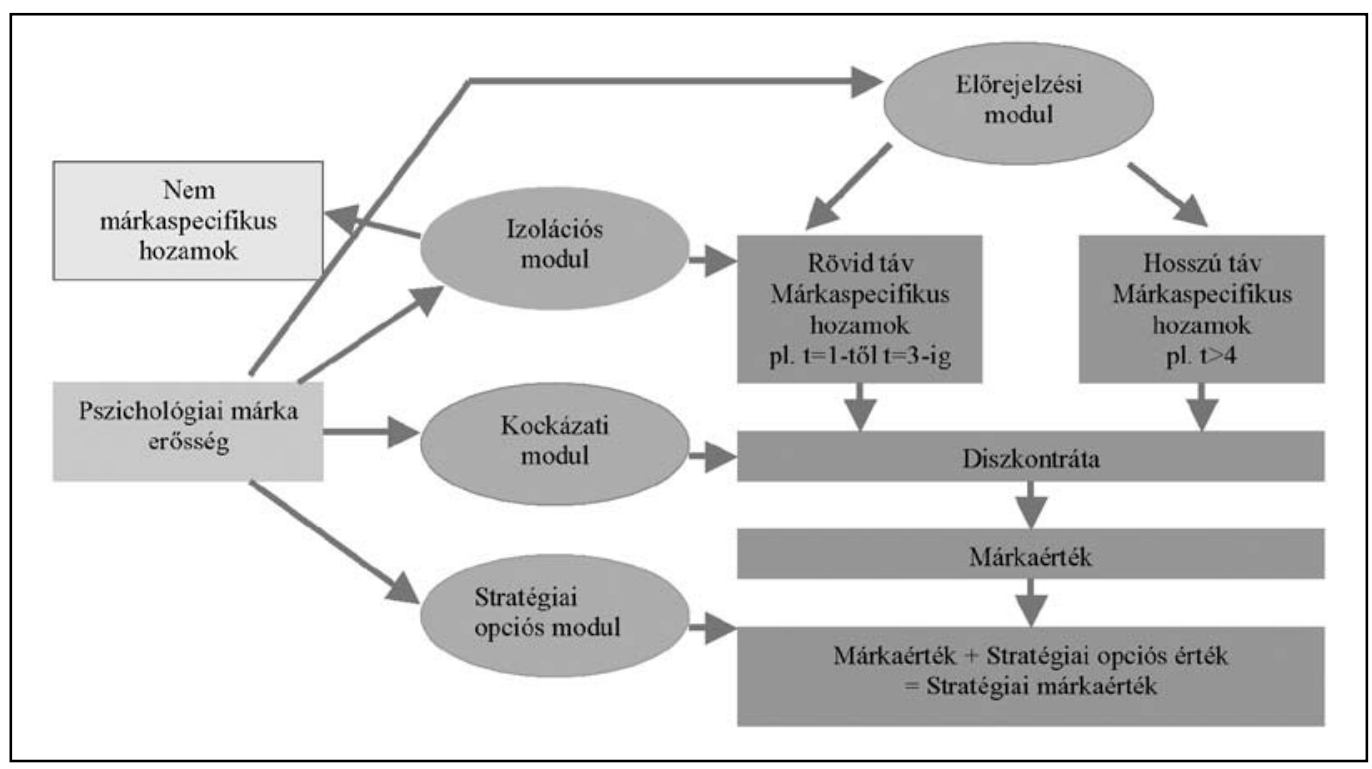

Forrás: Hupp - Powaga, 2004. pp. 227

erôsségének betudhatóan értékesített mennyiségi többlet. A márkaköltségek lehetnek közvetlenek, mint pl. a magasabb minőség vagy az egyedi design előállítása, és közvetettek is, mint pl. a disztribúció támogatása. Így a márkaspecifikus hozzáadott bevételek és kiadások különbsége adja a márkaspecifikus profitot.

Az előrejelzési modul a márkaspecifikus profitot rövid távra vagy hosszú távra vetíti ki. A magas BPI-vel rendelkezó erôs márkák esetében az átlagnál gyorsabb növekedéssel számolnak.

Minthogy a jövóbeni márkaspecifikus profit nagysága bizonytalan, kockázati modul is szerepel az ABV modellben. A márkakockázat független a vállalati kockázattól, és a BPI, vagyis a pszichológiai erőssége alapján határozzák meg, az erôs márkákhoz alacsony kockázati prémium járul és épül be a diszkontrátába.

A negyedik modul stratégiai opciókat foglal magában, amelyek nem szerepelnek az üzleti tervben. Bizonyos vállalatok számára egy megvásárolt márka szinergiák sorát biztosíthatja, hatékonyabbá teheti például a termelést, a disztribúciót, vagy a földrajzi terjeszkedést. Az erős márkák esetében sokkal nagyobb a valószínúsége a szinergiahatás elérésének, így a BPI alapján történik e modul számszerúsítése (Hupp - Powaga, 2004; Mussler - Hupp - Powega, 2004).

\section{A márkaértékelés kritikája és esetleges veszélyei}

A márkák pénzügyi értékelésével kapcsolatban konzervatív nézeteket vallók ellene vannak a márkák mérleg- nésének. Alapvetően azért, mert a márkaértékelést nagyon szubjektívnak tekintik, amely az egyes módszerektól és az értékelést végzô szakemberektôl függően rendkívül eltérô eredményre vezethet. Úgy vélik továbbá, hogy a márkák által generált profitot nem lehet elválasztani a vállalat többi materiális és nem materiális eszköze által létrehozott vagyontárgytól. Azt is feltételezik, hogy a befektetók saját előrejelzéseik, becsléseik alapján döntenek, és így pedig szükségtelen a márkaértékelés (Doyle, 2002).

Egyes szakemberek helytelen ok-okozati összefüggést állítanak fel a márkaértékelés kapcsán (elfogadható mértékú korreláció esetén). Azt állítják, hogy a márkaérték határozza meg a jövóbeni profitot és a részvényárakat. Ez azonban nem helytálló. A legtöbb pénzügyi márkaértékelési módszer pont hogy a jövôbeni cash flow elôrejelzésén alapul, vagyis fordított a viszony az elóbb említett tényezók között, és a márkaérték az, amelyre hatást gyakorolnak a pénzügyi mutatók (Ambler, 2003).

\section{Összegzés}

Amint a vállalatok értékében és a generálható profit nagyságában mind nagyobb szerepet játszanak a márkák, egyre fontosabbá válik a márkák pénzügyi értékelése: az eredményesség mértékeként szolgál, és meghatározó a márkákkal kapcsolatos menedzseri döntéshozatal során. A márkák pénzügyi értékre gyakorolt hatása a befektetóktoól a fogyasztókig, az ellátási lánc minden tagját érinti. Az eszmei vagyontárgyak egy fontos csoportját képezik, a mérlegbe azonban csak a vásárolt márkák kerülhetnek be, a saját fejlesztésúek nem. Az alkalmazandó márkaértékelési módszert mindig a célnak megfelelóen kell megválasztani. A technikákat rendszerint négy kategóriába sorolják: költségalapú, piaci alapú, jövedelemalapú és szabályszerú megközelítések. 


\section{Lábjegyzet}

1 A szakirodalomban nem találtam arra vonatkozóan információt, hogy miként határozzuk meg a diszkontráta mértékét, hogy egyenlővé tegyük a különböző időpontokban felmerült, múltbeli költségeket a jelenre, vagy egy adott időpontra vetítve.

${ }^{2}$ A BPI a GfK által kifejlesztett és az egész világon használt index számos különböző termék és szolgáltatás kategóriában. Kimutatták, hogy erósen korrelál a vásárlói húséggel és a piaci részesedéssel, valamint függ olyan kontrollálható marketingtevékenységektốl mint a reklám, a promóció vagy a disztribúció (Mussler - Hupp - Powega, 2004).

\section{Felhasznált irodalom}

Aak, L. - Brokaw, A. - Miljan, M. (2004): Implementing Brand Valuation in Marketing Management: Estonian Food Industry Cases. TUTWPE(BPE) No. 04/104 pp. 9-24

Ambler, T. (2003): Marketing: the trouble with finance. Business Strategy Review, Vol. 14, No. 3, pp. 54-62

Avery, H.G. (1942): Accounting for Intangible Assets. The Accounting Review, Vol. 17, No. 4. pp. 354-363

Bahadir, S.C. - Bharadwaj, S.G. - Srivastava, R.K. (2006): Financial Value of Brands in Mergers and Acquisitions: Is Value in the Eye of the Beholder? Goizueta Business School, Zyman Institute of Brand Science. Zyman Institute of Brand Science honlapja: www.zibs.com Letöltés ideje: 2007. 03. 02.

Best Global Brands 2006 (2007): A Ranking by Brand Value. Interbrand honlapja www.interbrand.com Letöltés ideje: 2007. 02. 20.

BrandFinance 250 (2007): The Annual Report on the World's Most Valuable Brands. Brand Finance honlapja www.brandfinance.com Letöltés ideje: 2007. 02. 20.

Brymer, C. (2004): What Makes Brands Great. A Chapter from Brands and Branding. An Economist Book. pp.18. Interbrand honlapja: www.interbrand.com Letöltés ideje: 2007. 02. 20.

Cravens, K.S. - Guilding, C. (1999): Strategic Brand Valuation: A Cross-Functional Perspective. Business Horizons, Vol. 42, No. 4, pp. 53-62

Cravens, K.S. - Guilding, C. (2000): Measuring Customer Focus: An Examination of the Relationship between Market Orientation and Brand Valuation. Journal of Strategic Marketing, Vol. 8, No. 1, pp. 27-45

De Chernatony, L. - McDonald, M. (2005): Creating powerful brands in consumer, service and industrial markets. Oxford, Boston [Mass.]: Elsevier Butterworth - Heinemann

Doyle, P. (2002): Értékvezérelt marketing: A részvényesi értéket és a vállalati növekedést támogató marketingstratégiák. Budapest: Panem

Farquhar, P.H. - Han, J.Y. - Ijiri, Y. (1992): Brands on the Balance Sheet. Marketing Management, Vol. 1, No. 1, pp. 16-22
Fernández, P. (2002): Valuation of Brands and Intellectual Capital. Research Paper No. 456. Univeristy of Navarra, Barcelona. IESE honlapja: www.iese.edu Letöltés ideje: 2007. 03. 03.

Global Intangible Tracker 2006 (GIT ${ }^{\mathrm{TM}}$ 2006): An Annual Review of the World's Intangible Value. Brand Finance honlapja: www.brandfinance.com Letölt. ideje: 2007. 02. 20.

Haigh, D. (2003): Brand Valuation: What It Means and Why It Matters. In: Brands in the Boardroom. IAM supplement No. 1, pp. 18-21. Brand Finance honlapja: www.brandfinance.com Letöltés ideje: 2007. 02. 20.

Haigh, D. - Knowles, J. (2004): How to Define Your Brand and Determine Its Value. Marketing Management, Vol. 13 , No. 3, pp. 22-28

Harter, G. et al. (2004): Managing Brands for Value Creation. Booz Allen Hamilton honlapja: www.boozallen.de Letöltés ideje: 2007. 03. 02.

Hupp, O. - Powaga, K. (2004): Using Consumer Attitudes to Value Brands: Evaluation of the Financial Value of Brands. Journal of Advertising Research, Vol. 44, No. 3, pp. 225-231

Intangible Business (2002): Brand Valuation in Brand Management \& Performance Measurement. Intangible Business honlapja: www.intangiblebusiness.com Letöltés ideje: 2007. 03. 02.

Jones, R. (2005): Finding Sources of Brand Value: Developing a Stakeholder Model of Brand Equity. Brand Management, Vol. 13, No. 1, pp. 10-32

Keller, K.L. - Lehmann, D.R. (2003): How Do Brands Create Value? Marketing Management, Vol. 12. No. 3. pp. 2631

Kotler, P. (1999): Marketingmenedzsment: elemzés, tervezés, végrehajtás és ellenőrzés. Budapest: Múszaki Könyvkiadó

Knowles, J. (2003): Value-based Brand Measurement and Management. Interactive Marketing, Vol. 5, No. 1, pp. 40-50.

Laboy, P. (2005): The Importance of Measuring Brand Value and Brand Equity. TOCQUIGNY, INC. honlapja www. tocquigny.com Letöltés ideje: 2007. 03. 02.

Lindemann, J. (2004): Brand Valuation. A Chapter from Brands and Branding. An Economist Book. pp.1-12. Interbrand honlapja: www.interbrand.com Letöltés ideje: 2007. 02. 20.

Mills, R. (2005): Brand Valuation. Henley Manager Update, Vol. 16, No. 3, pp.1-8

Mussler, S. - Hupp, O. - Powega, K. (2004): Evaluation of the Financial Value of Brands. GfK honlapja: www. gfkcr-ww.com Letöltés ideje: 2007. 03. 02.

Principles of BrandEconomics (2004): Adding Brand Value. Brand Finance honlapja: www.brandfinance.com Letöltés ideje: 2007. 03. 08.

Schultz, D.E. - Schultz, H.F. (2005): Measuring Brand Value. In: Kellogg on Branding: The Marketing Faculty of The Kellogg School of Management. (Szerk.: Tybout, A. M., Calkins, T.) Hoboken, N.J.: Wiley 
Seetharaman, A. - Nadzir, Z.A.B.M. - Gunalan, S. (2001): AConceptual Study on Brand Valuation. Journal of Product \& Brand Management, Vol. 10, No. 4, pp. 243-256.

Shaw, R. - Merrick, D. (2005): Marketing Payback: Is Your Marketing Profitable? Harlow: Financial Times/Prentice Hall

Simon, C.J. - Sullivan, M.W. (1993): The Measurement and Determinants of Brand Equity: A Financial Approach. Marketing Science, Vol. 12, No. 1, pp. 28-52

Srivastava, R.K. - Shervani, T.A. - Fahey, L. (1998): MarketBased Assets and Shareholder Value: A Framework for Analysis. Journal of Marketing, Vol. 62, No. 1, pp. 2-18.
Thomas, G. M. - Parkhurst, J.D. (2006): Suite Talk. Marketing Management, Vol. 15. No. 6. pp. 48-54.

Vaughan, J.L. (1972): Give Intangible Assets Useful Life. Harvard Business Review, Vol. 50. No. 5. pp. 127-132. Whitwell, S. (2007): Brand valuation: why \& how. Intangible Business honlapja: www.intangiblebusiness.com Letöltés ideje: 2007. 03. 08.

Wilson, R.M.S. (1986): Accounting for Marketing Assets. European Journal of Marketing, Vol. 20, No. 1, pp. 51-74

Cikk beérkezett: 2007. 10. hó

Lektori vélemény alapján átdolgozva: 2008. 1. hó

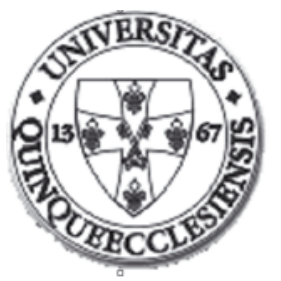

\title{
International Conference on
}

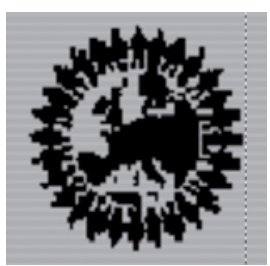

\section{"New Trends and Tendencies} in the Human Resource Management East meets West"

\section{Cranet Network \\ Pécs, 13-14, June 2008}

Abstract submission deadline is 15 March 2008.

The completed registration form is requested to be attached to the abstract.

Paper submission deadline is April 30, 2008.

For further information please contact:

\author{
Ágnes Király \\ kiralyagnes@ktk.pte.hu
}

or visit the website of the conference at

http://www.hrconference2008.ktk.pte.hu/index.php 